\title{
Newtron Network News「波紋」発刊に際して
}

物性研 山田 安定

我が国における中性子散乱研究は、現在ひとつの重要な転機を迎えている。

第 1 に原研 3 号炉の完成とこれに伴う中性子散乱設備計画の進展がある。この結果、特 に冷中性子源の利用により、原研の大学共同利用研究は、質量ともに飛躍的な充実を見る ものと期待される。

第 2 に、高エネルギー研におけるパルス中性子散乱研究の着実な発展があり、この実績 をふまえたハドロン計画を中心とする将来計画の策定によって、KENSは世界の研究セン ターとして発展をとげる展望が開けつつある。

一方、中性子散乱研究のように「巨大設備の共同利用」を必要とする研究には常につき まとう問題点がある。多くの利用者のニーズにできるだけ万遍なく対応できるデパート的 性格と、世界的レベルでユニークさを売り物にする高級専門店的性格を、どのようにバう ンスよく配するか、ハードゥエア面（装置の特性）でもソフト面（マシンタイムの配分な どの運営）でも問われる所である。世界の研究センターを眺めても、この点についての方 針は、それぞれ違っており、結局それがそのセンターの性格を決めているように思われ る。

現在、特に定常中性子に関して改 3 号炉の装置建設およびその運営のスタートという重 要な時期にあたり、多くの関係者各位、関心を持たれる方々に、ハード、ソフト両面に関 して現状について、詳しい情報を提供し、又そこからのフィードバックを次のステップに 活かすことは、我が国の中性子散乱研究の性格づけを、大方の研究者の理解と積極的な支 持の上に築き上げて行く上で、極めて大切なことと思う。

過日の物理学会インフォーマルミーティングの席上多くの方々から、特に 3 号炉共同利 用の運営について情報提供の必要性が強く指摘されたのも、正にこの点に関わることと受 けとめ、今回上記の趣旨から我が国の中性子散乱研究について、いろいろな面での情報交 換を目的とするNeutron Network News誌「波紋」が発行されることとなった。編集にあ たってくださる諸氏に御礼を申し上げるとともに、本誌が今後の中性子散乱共同研究の活 性化に資することを期待している。 
高エネ研 渡辺昇

前々から Neutron News Letter の国内版のようなものが是非必要だと思っていた一人とし て、関係者の努力により、この度「波紋」なるものが発行されるはこびとなったことは誠に 喜ばしい。

各国の中性子ソサイエティを多くの欧米人が評して、アメリカのそれは中小企業の集合、 それに対して、ヨーロッパは大企業という。では日本は？と聞けば小さな声で組合をもたな い零細企業という答えが返ってくる。

私のように高エネ研のような所にいると、高エネルギー物理は独占超大企業、放射光は大 企業、原子核は組合の発達した中小企業、中性子はやはり未組織零細企業なのである。学問 分野の性格上このような状態はある程度止むを得ないにしても、大型将来計画を唱う時には 迫力に欠けることこの上ない。どうしても他分野に対して発言権が小さくなってしまう。こ れを何とかしなくてはというのが、我が国の中性子を発展させたいと願う一人として、私の 頭の中に何時も存在するモヤモヤである。この「波紋」が広い意味での我が国の中性子研究 者の統一に、いささかでも寄与してほしいと念願する次第である。

改 3 号炉もほほ順調に稼働を始め、多くの測定器が新たにユーザーに開放されつつある。 大変結構なことである。いまどき原子炬がよい、いやパルスがよい、などという人は世界中 殆んどいない。それぞれ特徴があり、有用であることを多くの人が認識していると思う。最 近、東北大の遠藤教授から改 3 号炉の新しい 3 軸型分光器のデータを見せてもらったが、2 号炉時代に比べ計数率、SN比ともに数倍よくなっているのに感銘を受けた。恐らく通常の実 験ではBNLのHFBRに比べてほとんど遜色ないのではないかと察する。こうなると日米協力 「中性子散乱」の今後の進め方を考え直す必要があるばかりでなく、我が国の中性子ソサイ エティが中性子ビームの量質ともに新たな時代に入ったことを意味する。このことは、従来 存在した“中性子ビームに飢えた研究者” はしばらくの間はなくなるとともに、本当の意味 でより多くのグッド・サイエンスを育てなければならないことを意味する。中性子が一部の 研究者に独占された実験手段であることはもはや許されない。本来中性子散乱は非常に広い 研究分野で有用なプローブであるはずである。残念ながら我が国の中性子研究者は、広い ユーザー層を育てる余力もなかったが、その努力もあまりしなかったと反省せざるを得な い。KENSは開設以来その方向を目指したが、勿論理想からはほど遠い。広い分野での中性 子散乱あるいは中性子ビーム利用の健全な発展なしには、そして多くの分野の研究者の一致 した強力なサポートなしには、我が国の中性子の将来は存在し得ないのである。従来の狭義 の中性子研究者が、それぞれの専門分野でピークのある研究を達成しなければならないこと 
は当然であるが、これからはそれだけでは許されないのである。苦しくてもより広い分野の 研究者に協力して、それらの分野で中性子が何如に有用か成果で示さなければならない。さ らに我々は、アジア太平洋地域の国々の研究者に我が国の中性子ビームを積極的に開放し、 彼等の物質科学研究に協力して行くことも今後は是非皆さんと一緒に考えて行きたいもので ある。

“我が国の中性子は一つ”の実践を目指して、物性研を空口とする原子炉の共同利用と、高 エネ研を空口とするパルスの共同利用を有機的に運用する試みが始まった。具体的には双方 の課題探択委員会のメンバーをある程度オーバーラップさせ、それぞれにより適した課題の 振り分けを行おうというのである。両者の相補性からしてそれは当然である。また両者の研 究者が装置建設及び共同利用で相互乗り入れすることも始まっている。それと同時に両者の 間にある種の競争のメカニズムはよい意味で残しておきたいものである。

この「波紋」がこのような目標の達成にわずかながらでも貢献してほしいと念願するもの である。

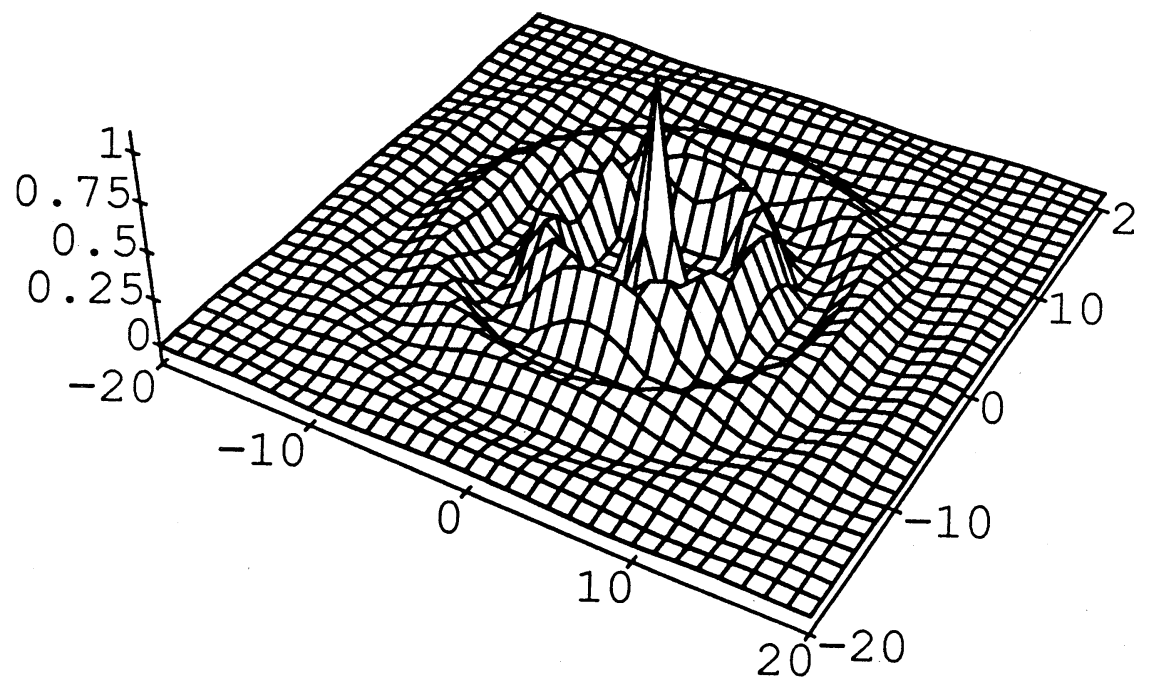

